\title{
Edyta Cieślak
}

Uniwersytet Ekonomiczny we Wrocławiu

e-mail: edyta.cieslak1@gmail.com

\section{ROZWÓJ KLASTRA OD INICJATYWY \\ DO FAZY WZROSTU \\ NA PRZYKŁADZIE KLASTRA SIDE-CLUSTER}

\section{CLUSTER DEVELOPMENT FROM THE INITIATIVE TO THE PHASE OF GROWTH ON THE EXAMPLE OF THE CLUSTER OF SIDE-CLUSTER}

DOI: $10.15611 / \mathrm{e} 21.2015 .2 .03$

JEL Classification: L74, O30, R11.

Streszczenie: Celem artykułu jest opisanie studium przypadku powstania i rozwoju zlokalizowanego na Dolnym Śląsku klastra branży budowlanej i drzewnej SIDE-CLUSTER. Zaprezentowane rozważania służą ukazaniu procesu oddolnego tworzenia klastra, ewolucji klastra oraz znaczenia w rozwoju regionu i sektora. Celem autorki jest wskazanie kluczowych czynników warunkujących powstanie klastra, zidentyfikowanie etapów jego wzrostu, zaznaczenia roli otoczenia zewnętrznego w procesie inkubacji i wzrostu klastra oraz czynników endogennych, tj. poziomu zaufania wewnątrz klastra. Rozważania oparto na analizie literatury przedmiotu i analizie badań empirycznych. Artykuł zawiera definicję klastra, opis faz rozwoju oraz charakterystykę klastra SIDE-CLUSTER: od fazy inicjatywy klastrowej do postaci aktualnej, tj. 6-letniego klastra. Autorka udowadnia, że SIDE-CLUSTER jest organizacją aktywnie działającą na Dolnym Śląsku i dynamicznie się rozwijającą.

Słowa kluczowe: klaster, inicjatywa klastrowa, konkurencyjność, innowacyjność, kooperacja.

Summary: The aim of this article is to present a case study of the creation and development of the construction of wood cluster - "SIDE-CLUSTER" located in Lower Silesia. The following considerations present a bottom-up process of cluster formation, its' evolution and the role of the cluster for the regional and sectoral development. The researcher's goal is to identify the key factors determining cluster development, to show the stages of its growth, the role of both the external environment in the process of incubation and the growth of the cluster and endogenous factors, i.e. thelevel of trust within the cluster. The considerations are based on an analysis of the literature and analysis of empirical research. The article contains a cluster definition, a description of the stages of development and the characteristics of the cluster of SIDE-CLUSTER from the phase of cluster initiative to its form nowadays - the 6-year-old cluster. The author proves that the cluster of SIDE-CLUSTER is a dynamic organization actively operating in the Lower Silesia.

Keywords: cluster, cluster initiative, competitiveness, innovation, cooperation. 


\section{Wstęp}

Celem autorki artykułu jest przedstawienie procesu powstawania i rozwoju klastra na przykładzie dolnośląskiego klastra branży budowlanej i drzewnej SIDE-CLUSTER.

Rozważania służą zaprezentowaniu procesu oddolnego tworzenia klastra, jego stopniowej ewolucji i dojrzewania, zidentyfikowania faz wzrostu, czynników sprzyjających oraz barier warunkujących tempo i kierunek rozwoju klastra. Badaczka wskazuje dwie metody powstawania klastrów i identyfikuje kluczowe czynniki je warunkujące, opisuje etapy wzrostu klastra, rolę i wpływ otoczenia zewnętrznego w procesie inkubacji i wzrostu klastra, a także znaczenie czynników endogennych, tj. poziomu zaufania wewnątrz klastra, zaangażowania członków i animatora klastra, motywację aktorów klastra.

Rozważania oparto na analizie literatury przedmiotu i analizie badań empirycznych. Zastosowaną $\mathrm{w}$ artykule metodą badawczą jest studium przypadku. W procesie badawczym wykorzystano technikę badania dokumentacji, obserwacji w połączeniu z doświadczeniem gospodarczym autorki. Artykuł przedstawia charakterystykę klastra SIDE-CLUSTER: od fazy inicjatywy klastrowej do postaci aktualnej, tj. klastra 6-letniego. Autorka udowadnia, że klaster SIDE-CLUSTER jest organizacją aktywnie działającą na Dolnym Śląsku, dynamicznie się rozwijającą, sprzyjającą rozwojowi przedsiębiorczości w regionie. SIDE-CLUSTER jest organizacją nie tylko działającą na rynku regionalnym, ale również prowadzącą współpracę ponadregionalną i międzynarodową.

\section{Definicja klastra i inicjatywy klastrowej}

Istnieje wiele definicji klastra, jako że problematyka klastrów dyskutowana jest przez licznych badaczy, definiujących to pojęcie w różny sposób. W niniejszym artykule przyjęto definicję M. Portera [Porter 2000], według której klaster to „znajdująca się w geograficznym sąsiedztwie grupa przedsiębiorstw i powiązanych z nimi instytucji zajmujących się określoną dziedziną, połączona podobieństwami i wzajemnie się uzupełniająca". Zastosowanie mają tu również definicje pokrewne, stwierdzające, że: „klaster to geograficzne skupisko firm, pomiędzy którymi występują powiązania poziome i pionowe, które współpracują i konkurują ze sobą w ramach określonego segmentu rynku, korzystają ze wspólnej lokalnej infrastruktury i utożsamiają się z tą samą wizją rozwoju branży i regionu" [Cooke 2002] oraz że „klaster to geograficzne skupisko wyspecjalizowanych firm (głównie małych i średnich) działających w pokrewnych sektorach, powiązane z siecią publicznych i prywatnych instytucji wspierających ich aktywność. Pomiędzy przedsiębiorstwami występują powiązania rynkowe i pozarynkowe wynikające z wymiany dóbr i informacji. Zachowania poszczególnych firm są determinowane przez poczucie więzi i wspólnoty z innymi firmami z pokrewnych sektorów działających w tej samej lokalizacji” [Rabellotti 1995]. 
W literaturze nie ma jednoznaczności co do definicji klastra, za jego najistotniejszą cechę charakterystyczną należy jednak uznać istnienie wewnętrznych relacji i powiązań o charakterze systemowym oraz równoczesne występowanie konkurencji i współpracy między poszczególnymi podmiotami go tworzącymi. Istotne jest, aby odróżnić klaster od tzw. inicjatyw klastrowych.

\subsection{Inicjatywa klastrowa, metody tworzenia klastrów}

Inicjatywa klastrowa to mniej lub bardziej zinstytucjonalizowana (sformalizowana) grupa aktorów lokalnych, dążących do zainicjowania funkcjonowania danego klastra bądź rozwiązania istotnych problemów klastra już istniejącego.

Uruchomienie inicjatywy klastrowej może być wynikiem bądź oddolnych działań podmiotów gospodarczych zainteresowanych współpracą (podejście bottom-up), bądź działań odgórnych podejmowanych przez władze publiczne (podejście top-down) [Kierunki i polityka... 2009]. Podobną definicję inicjatywy klastrowej podali Ch. Ketels i wsp. [Ketels, Lindqvist, Solvell 2007]: „Inicjatywa klastrowa jest świadomą inicjatywą, mającą na celu w sposób bardziej zorganizowany wpłynąć na potencjał rozwoju danego klastra. W inicjatywę zaangażowani są kluczowi gracze danego klastra - przedstawiciele sektora gospodarczego, naukowego, publicznego".

Klastry są w Polsce względnie nowymi formami współpracy, jednakże $\mathrm{z}$ roku na rok stają się coraz bardziej popularne, koncepcja klastra stanowi bowiem punkt wyjścia do nowego sposobu myślenia o kreowaniu międzynarodowej konkurencyjności gospodarki krajowej i regionalnej - konkurencyjności rozumianej jako kompleksu czynników warunkujących stabilny rozwój społeczny i gospodarczy regionu, oparty na sektorowej specjalizacji i współpracy przedsiębiorstw. Gospodarczo uzasadnione jest tworzenie klastrów oddolnych, powstałych w wyniku rzeczywistych potrzeb lokalnej przedsiębiorczości [Kierunki i polityka ... 2009].

\section{Powstanie i charakterystyka klastra SIDE-CLUSTER}

Klaster drzewny SIDE-CLUSTER (pierwszy człon nazwy to akronim: S - sukces, I - innowacja, D - drewno, E - ekologia) powstał w październiku 2009 r. Jednak inicjatywa klastrowa pojawiła się już w połowie $2008 \mathrm{r}$. Inspiracją do jej powstania był wyjazd grupy dolnośląskich przedsiębiorców i lokalnych działaczy na wizytę studyjną do Finlandii. Celem wizyty było poznanie sytuacji ekonomiczno-społecznej Finlandii Środkowej oraz określenie możliwych płaszczyzn współpracy między Związkiem Gmin Środkowej Bothnii z siedzibą w Kokkola oraz Dolnym Śląskiem. Podczas wizyty uczestnicy obserwowali m.in. funkcjonowanie łańcuchów transakcji, grup zakupowych, poznali specyfikę tworzenia i funkcjonowania klastrów. Dobre praktyki we współpracy w ramach klastra zaobserwowane w Finlandii stały się zalążkiem do powstania inicjatywy klastrowej dążącej do utworzenia klastra branży budowlanej i drzewnej na Dolnym Śląsku. 
SIDE-CLUSTER jest przykładem inicjatywy oddolnej, powołanej w odpowiedzi na potrzeby mikro-, małych i średnich przedsiębiorstw branży budowlanej, drzewnej i okołobudowlanej, które we współpracy (rozumianą jako współpraca trójsektorowa), utworzeniu sieci powiązań i transferze innowacji widziały szansę swojego rozwoju.

Jesienią 2009 r. 15-osobowa grupa inicjatywna powołała stowarzyszenie o nazwie SIDE CLUSTER, które stało się liderem klastra SIDE-CLUSTER. Na początku swojego istnienia klaster miał 17 członków, aktualnie liczba ta wzrosła do 53 i wciąż obserwuje się zainteresowanie kolejnych firm przystąpieniem do klastra.

\subsection{Członkowie klastra SIDE-CLUSTER}

Firmy członkowskie klastra posiadają wieloletnie doświadczenie w branży budowlanej i drzewnej. Oferują swoje produkty i usługi na rynek krajowy i na rynki zagraniczne. Potencjał firm stanowi bardzo dobrze wykwalifikowana kadra specjalistów

Tabela 1. Liczba członków klastra SIDE-CLUSTER w latach 2009-2014

\begin{tabular}{|c|c|}
\hline Rok & Liczba członków klastra \\
\hline 2009 & 17 \\
\hline 2010 & 21 \\
\hline 2011 & 26 \\
\hline 2012 & 39 \\
\hline 2013 & 48 \\
\hline 2014 & 53 \\
\hline
\end{tabular}

Źródło: obliczenia własne na podstawie danych klastra SIDE-CLUSTER.

Liczba członków klastra w latach 2009-2014

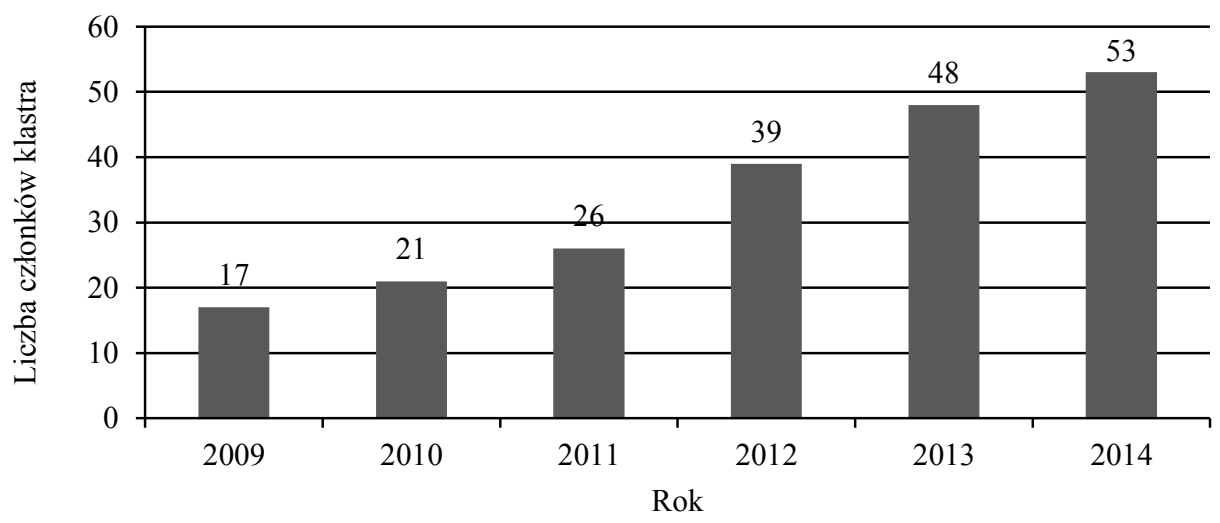

Rys. 1. Wykres dla danych $\mathrm{z}$ tab. 1

Źródło: obliczenia własne na podstawie danych klastra SIDE-CLUSTER. 
Tabela 2. Struktura członków klastra SIDE-CLUSTER w latach 2009-2014

\begin{tabular}{|c|c|c|c|}
\hline Rok & $\begin{array}{c}\text { Mikro-, małe i średnie } \\
\text { przedsiębiorstwa (MSP) }\end{array}$ & $\begin{array}{c}\text { Instytucje otoczenia biznesu } \\
\text { (IOB) }\end{array}$ & $\begin{array}{c}\text { Instytucje badawczo- } \\
\text {-rozwojowe (B+R) }\end{array}$ \\
\hline 2009 & 16 & 1 & 1 \\
\hline 2010 & 18 & 2 & 1 \\
\hline 2011 & 23 & 2 & 1 \\
\hline 2012 & 35 & 3 & 1 \\
\hline 2013 & 44 & 3 & 1 \\
\hline 2014 & 49 & 3 & \\
\hline
\end{tabular}

Źródło: obliczenia własne na podstawie danych klastra SIDE-CLUSTER.

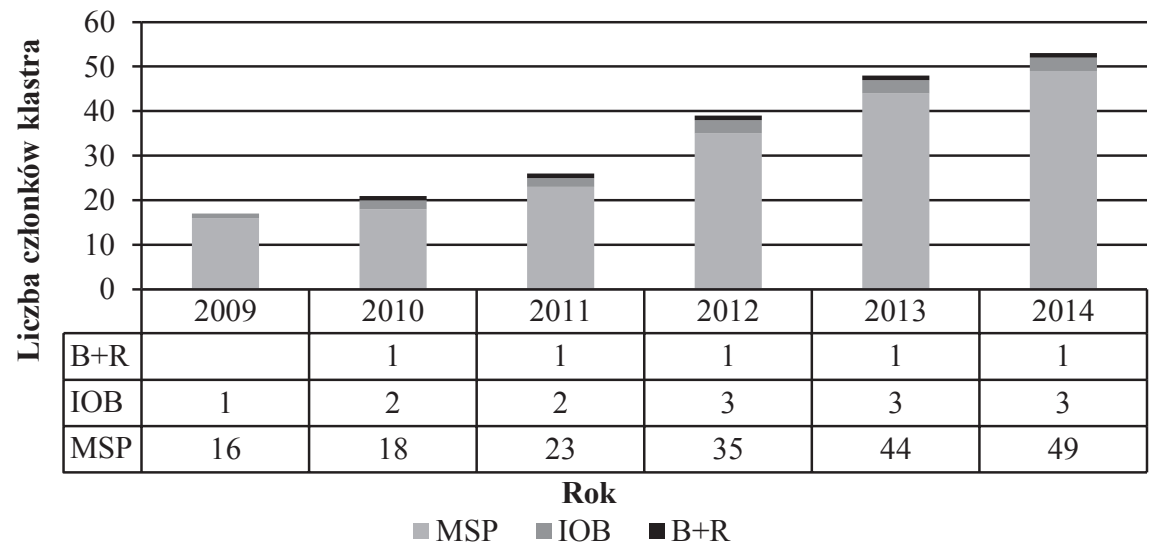

Rys. 2. Wykres dla danych z tab. 2.

Źródło: obliczenia własne na podstawie danych klastra SIDE-CLUSTER.
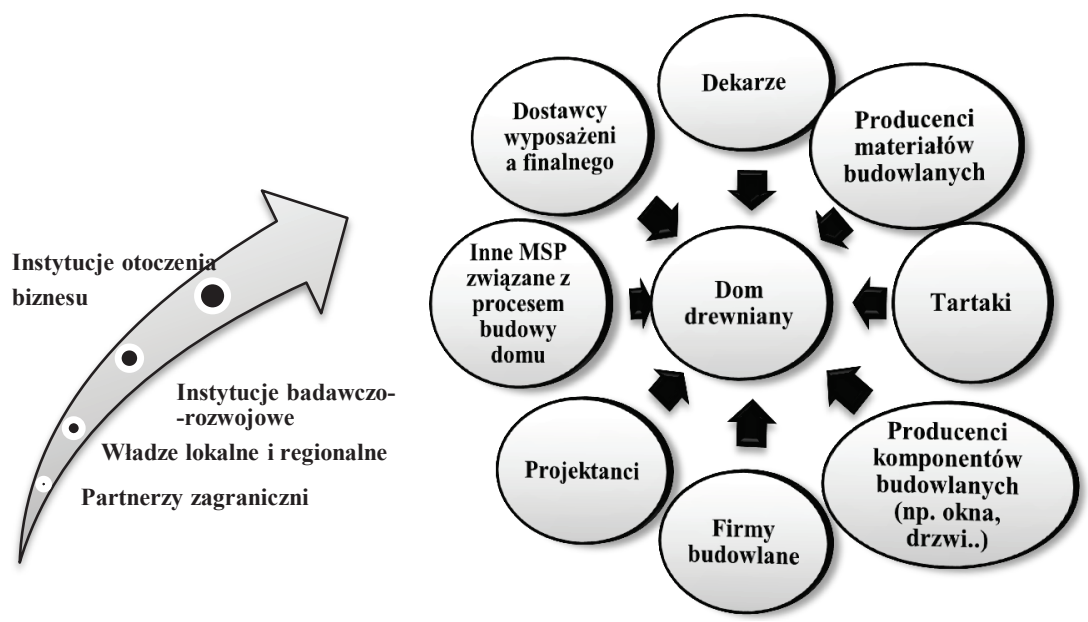

Rys. 3. Struktura klastra SIDE-CLUSTER

Źródło: opracowanie własne na podstawie danych klastra SIDE-CLUSTER. 
poszczególnych etapów produkcji obiektów budowlanych (od zagospodarowania gruntu, poprzez prace projektowe, produkcję materiałów, do wykończenia nieruchomości).

Aktualne w klastrze zrzeszone są 53 podmioty; są nimi:

- 49 firmy z sektora MSP (z czego 41 to mikro-, 6 - małe, 2 - średnie przedsiębiorstwa),

- 3 instytucje otoczenia biznesu (IOB),

- 1 uczelnia wyższa (Międzynarodowa Wyższa Szkoła Logistyki i Transportu we Wrocławiu).

\subsection{Partnerzy klastra SIDE-CLUSTER}

Klaster współpracuje z partnerami krajowymi i zagranicznymi, wśród których wymienić należy:

- Izbę Inżynierów Budownictwa z siedzibą we Wrocławiu,

- Cech Rzemiosł Budowlanych we Wrocławiu,

- Agencję Rozwoju Regionalnego ARLEG S.A. w Legnicy,

- Związek Pracodawców Polska Miedź z siedzibą w Legnicy,

- Polską Akademię Nauk,

- Politechnikę Wrocławską,

- pracowników naukowych Uniwersytetu Przyrodniczego we Wrocławiu,

- Urząd Marszałkowski Województwa Dolnośląskiego,

- Urząd Miejski w Jaworze,

- Urząd Miejski w Legnicy,

- Urząd Miasta i Gminy w Prochowicach,

- Centria Research and Development (Kokkola, Finlandia),

- Keski-Pohjanmaan Liitto (Kokkola, Finlandia),

- EduCluster Finlad Ltd. (Jyvaskyla, Finlandia),

- Teijo-Talo Oy (Pernio, Finlandia),

- Eichenbaum GmbH (Gotha, Niemcy),

- THOR Industriemontagen GmbH (Erfurt, Niemcy),

- Università Verde di Bologna (Bolonia, Włochy),

- EMAFA Klaster (Eger, Węgry).

Od listopada 2012 r. klaster SIDE-CLUSTER jest partnerem stowarzyszonym (affiliate partner) europejskiej organizacji CLIMATE- KIC i Wrocławskiego Centrum Badań EIT+. Ponadto SIDE-CLUSTER jest członkiem Dolnośląskiej Federacji Organizacji Pozarządowych (DFOP), European Cluster Collaboration Platform, uczestniczy $\mathrm{w}$ procesie tworzenia europejskiego metaklastra $\mathrm{w}$ ramach projektu CLUSTERS CORD [www.clusterscord.eu]. 


\subsection{Charakterystyka i rozwój klastra SIDE-CLUSTER}

SIDE-CLUSTER jest organizacją stymulującą postęp technologiczny w branży budowlanej. Wspiera firmy we wprowadzaniu innowacyjnych rozwiązań i w popularyzacji osiągnięć technologicznych oraz organizacyjnych z zakresu budownictwa drewnianego i jego otoczenia. SIDE-CLUSTER skupia miro-, małe i średnie przedsiębiorstwa $z$ sektora budowlanego i drzewnego oraz instytucje naukowo-badawcze i ośrodki wspierające rozwój regionalny na terenie Dolnego Śląska i Opolszczyzny. SIDE-CLUSTER zlokalizowany jest w południowo-zachodniej Polsce, większość firm zrzeszonych w klastrze pochodzi zaś z województwa dolnośląskiego.

Klaster tworzy platformę współpracy między lokalnymi firmami, otoczeniem gospodarczym i samorządowym, jednostkami $\mathrm{B}+\mathrm{R}$, instytucjami otoczenia biznesu, partnerami zagranicznymi. Połączenie sił, wiedzy, doświadczeń w klastrze pozwala na osiągnięcie efektu synergii i przyczynia się do uzyskania trwałej przewagi konkurencyjnej, efektywniejszego transferu wiedzy i technologii, dynamicznego wprowadzania innowacji. Współpraca i bliskość podmiotów klastra wypływają na dyfuzję innowacji poprzez intensyfikację procesu uczenia się, niwelując jednocześnie ryzyko i obniżając koszty transakcyjne, umożliwia też specjalizację.

SIDE-CLUSTER jest przykładem inicjatywy oddolnej, która stopniowo się rozwijała, kreując swoje cele, działania, umacniając swoją strukturę i pozycję rynkową. Dużą rolę w procesie tworzenia i rozwoju SIDE-CLUSTER odegrało wsparcie otrzymane w formie dotacji z budżetu województwa dolnośląskiego w latach 2009-2013, które pozwoliło na przeprowadzenie wielu działań prowadzących do zbudowania struktury i wypracowania wzajemnego zaufania w klastrze, szerzenia wiedzy i zwiększenia świadomości społeczeństwa Dolnego Śląska na temat klasteringu oraz ekologicznego budownictwa drewnianego, umocnienia kontaktów z partnerem fińskim oraz nawiązania współpracy z partnerami we Francji oraz w Niemczech (potencjalnymi odbiorcami produktów klastra), zbudowania silnych podstaw do podjęcia kroków prowadzących do rozpoczęcia procesu inwestycyjnego. Niestety, wsparcie dla klastrów nie ma charakteru działania ciągłego, nie pozwala na zaplanowanie długofalowych działań i zagwarantowanie finansowania podstawowych potrzeb klastra w początkowej fazie jego rozwoju.

SIDE-CLUSTER stanowi aktualnie wzorzec dla nowo tworzących się sieci współpracy, nowo powstające inicjatywy klastrowe biorą przykład z SIDE-CLUSTER, a prezes i menedżer klastra, jako doradcy, uczestniczą w procesie tworzenia kolejnych inicjatyw klastrowych na Dolnym Śląsku, w województwach opolskim i lubuskim, prowadzą szkolenia z zakresu klasteringu, inspirują do tworzenia sieci.

\subsection{Firmy sektora MSP głównymi aktorami w klastrze SIDE-CLUSTER}

W Polsce działa ok. 1,8 mln przedsiębiorstw, z czego ponad 99,5\% tworzą MSP ${ }^{1}$. W podstawie danych GUS, przygotowanych na potrzeby Raportu o stanie sektora

${ }^{1}$ Dane GUS za 2011 r. 
MSP w Polsce w latach 2011-2012 opracowanego przez PARP [Raport o stanie sektora MSP... 2013], działające w Polsce przedsiębiorstwa generują blisko trzy czwarte polskiego PKB (71,8\% w $2011 \mathrm{r}$.). W strukturze udziału w PKB przedsiębiorstw MSP generują co drugą złotówkę (47,3\%), w tym najmniejsze firmy - blisko co trzecią (29,4\%). Pod względem liczby przedsiębiorstw Polska jest szóstą gospodarką Unii Europejskiej, a w porównaniu ze średnią unijną sektor MSP w Polsce jest W większym stopniu zdominowany przez mikroprzedsiębiorstwa (96\% w Polsce, 92\% w UE) [Small Business ... 2012]. Sektor MSP stwarza ok. 6,3 mln miejsc pracy (na 9 mln osób pracujących ogółem w przedsiębiorstwach)².

Promowanie idei klasteringu przyczynia się znacznie do wzmocnienia potencjału MSP, stopnia ich internacjonalizacji, innowacyjności i specjalizacji technologicznej, co jest niezmiernie istotne w czasach wysokiej konkurencji, podczas dążenia do wyspecjalizowanej gospodarki, w okresie spowolnienia gospodarczego. „W klastrze występuje większa motywacja do wydajnej pracy i lepsze możliwości pomiaru jej efektywności. Przedsiębiorstwa w klastrze mogą często szybciej i lepiej rozpoznawać potrzeby i szanse innowacji niż wyizolowani konkurenci” [Rymarczyk 2012].

SIDE-CLUSTER prowadzi ciągłą promocję klasteringu jako efektywnej i trwałej sieci współpracy, pokazując korzyści z uczestniczenia w takiej formie organizacyjnej na przykładzie własnym, firm zrzeszonych, a także wykorzystując przykłady innych klastrów krajowych i zagranicznych.

W przeszło sześcioletnim okresie funkcjonowania SIDE-CLUSTER wypracował sieć rzeczywistych powiązań gospodarczych między członkami, wpływających na realną poprawę warunków ekonomicznych firm, zwiększających ich przewagę konkurencyjną, motywujących do dalszego rozwoju i podejmowania nowych wyzwań (np. tworzenia konsorcjów celowych przez członków klastra i realizacji dużych zleceń, podejmowania nowych kierunków działalności firm, rozwoju oferty produktów i usług, zwiększania poziomu wiedzy i kompetencji biznesowych, otwarcia na nowe rynki, w tym zagraniczne). Jednakże, aby ten zapoczątkowany proces dalej istniał i się rozwijał, niezbędne jest ciągłe wsparcie (merytoryczne i społeczne) ze strony klastra, poszukiwanie nowych rozwiązań pojawiających się problemów, dbanie o kontakty interpersonalne, ciągłe budowanie zaufania między członkami klastra. Jak wynika z najnowszych badań polskich klastrów, społeczne życie w tego rodzaju strukturach, choć istnieje, powinno być znacznie intensywniejsze; wymaga też ciągłego pobudzania, podtrzymywania zapoczątkowanych więzi [Cluster Benchmarking... 2010]. Podzielając pogląd European Cluster Alliance (ECA) oraz redaktora naczelnego „Biznes Klaster” W. Wierżyńskiego [Wierżyński 2010], stwierdzić można, iż uwzględniając społeczne aspekty funkcjonowania klastrów - kwestie zaufania, budowania nowych relacji między firmami, zacieśniania współpracy nie tylko w sensie biznesowym, ale także personalnym, struktury te można uznać za wyjątkowo cenną i zaawansowaną formę powiązań między podmiotami gospodarczymi.

2 Dane GUS za 2011 r. 
Aby jednak inicjatywy klastrowe mogły się rozwijać, konieczne jest pokonanie barier mentalnych wynikających z niedostatku w sferze publicznej zaufania do uczestników gry gospodarczej, ich słowności, kultury biznesowej czy wręcz uczciwości. Zaufanie, ten najcenniejszy element kapitału społecznego, jest tutaj podstawą do tworzenia jakiejkolwiek struktury sieciowej współpracy.

\subsection{Fazy rozwoju klastra}

Fazy rozwoju klastra można zobrazować za pomocą jego cyklu życia, który przedstawiono na rys. 4.

W fazie embrionalnej klastra zainteresowane współpracą podmioty realizują wspólne przedsięwzięcia. Ważną rolę na tym etapie odgrywają liderzy branży, którzy dążą do utworzenia klastra.

W fazie wzrostu klastry powiększają swój potencjał, skupiają kolejne podmioty: przedsiębiorstwa, instytucje otoczenia biznesu, jednostki naukowe. Rośnie ich znaczenie na rynku, marka staje się rozpoznawalna, ich lokalna przewaga konkurencyjna umożliwia kontynuację podjętych działań innowacyjnych.

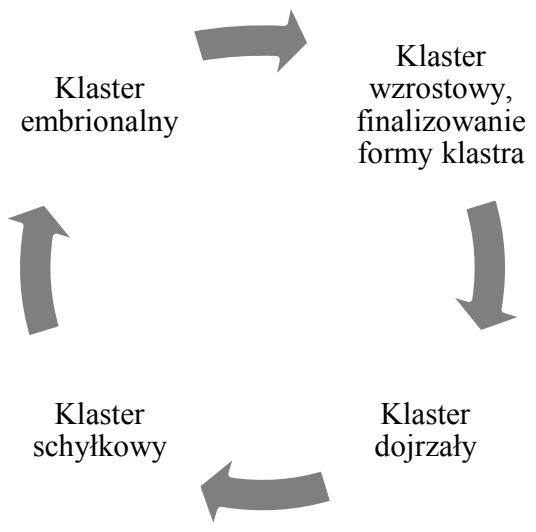

Rys. 4. Cykl życia klastra

Źródło: [A Practical Guide... 2004].

Wkroczenie klastra w fazę dojrzałości charakteryzuje się stabilizacją liczby podmiotów działających w ramach klastra lub jej zmniejszeniem, a standardowy charakter procesów produkcyjnych i usług oferowanych na rynku wymaga znalezienia nisz rynkowych lub zwiększenia produktywności firm, gdyż rozwiązania wykorzystywane przez przedsiębiorstwa podlegają upowszechnieniu i możliwe jest ich względnie łatwe kopiowanie.

Klastry w fazie schyłkowej wykazują dwojaki sposób zachowań rynkowych: niektóre z nich, ze względu na słabą pozycję konkurencyjną spowodowaną m.in. 
niezastosowaniem nowych rozwiązań technologicznych, organizacyjnych czy marketingowych, brakiem przepływu informacji, powoli zaprzestają działania, inne natomiast przekształcają się i dostosowują do zmian w otoczeniu i mogą ponownie rozpocząć cykl życia.

\section{Faza rozwoju klastra SIDE-CLUSTER}

SIDE-CLUSTER jest klastrem rozwijającym się. Aktualnie jest w fazie wzrostu, zbliża się do fazy finalizowania kształtowania swojej formy, prowadzenia działań inwestycyjnych zapewniających mu dalsze samofinansowanie. Obserwowany jest ciągły wzrost liczby podmiotów działających w ramach klastra, co wpływa na wzmocnienie i zdywersyfikowanie jego potencjału, wzmocnienie pozycji rynkowej i konkurencyjności. Marka SIDE-CLUSTER jest coraz bardziej rozpoznawana na Dolnym Śląsku, w Polsce, a nawet za granicą.

\section{Znaczenie klastra w rozwoju regionu}

\subsection{Wybór branży}

Jak wynika z raportu pt. Identyfikacja istniejących i potencjalnych klastrów na Dolnym Śląsku, opracowanego przez ECORYS Polska Sp. z o.o. na zlecenie UMWD w 2009 r., rozwój klastra do stadium dojrzałego zajmuje około 10 lat, a dojrzały klaster może funkcjonować następne 25 lat. Bez wsparcia w postaci dotacji ze środków samorządu wzrost będzie przebiegał znacznie wolniej i w ograniczonym zakresie.

Stosując się do wskazówek M. Portera [Porter 1990], podczas budowy klastra należałoby wyselekcjonować te branże, sektory w danej gospodarce narodowej, które są konkurencyjne na arenie międzynarodowej [Gorynia 2008]. Porter zaleca oparcie oceny ich konkurencyjności na dwóch wskaźnikach; są nimi: udział danej branży w rynku światowym oraz wartość zagranicznych inwestycji bezpośrednich podejmowanych przez uczestników danej branży. Jednakże, jak zauważają E. Peters i N. Hood [Peters, Hood 2000], ograniczanie się tylko do danych statystycznych może powodować pomijanie niektórych sektorów czy branż lub może prowadzić do zbyt szerokiego nakreślania granic klastra. W celu uniknięcia pomyłek Gorynia [Gorynia 2008] sugeruje skorzystać z zestawu warunków koniecznych i wystarczających do kreacji klastra, które zaproponowali C. Steinle i H. Schiele [Steinle, Schiele 2002]. Do tworzenia klastra konieczna jest podzielność procesu produkcji widoczna poprzez występowanie specjalizacji w ramach łańcucha tworzenia wartości na poszczególne fazy oraz możliwość transportu produktów. Proces produkcji musi być na tyle rozbudowany, aby możliwa były jego fragmentacja i występowanie konkurencji przynajmniej kilku firm na każdym etapie procesu oraz wzajemne uczenie się.

Warunkami wystarczającymi do kreacji klastra są: konieczność koordynacji wielu komponentów składających się na produkt finalny, obecność komplementarnej wiedzy $\mathrm{w}$ ramach systemu tworzenia wartości, kooperacja między podmiotami, 
sprzyjająca kreowaniu innowacji, zmienność i dynamika rynku oraz duże zróżnicowanie popytu. Warunki te sugerują, które branże są bardziej podatne na tworzenie klastrów. Najczęściej dochodzi do spontanicznego tworzenia się klastrów, co jako pierwszy zaobserwował A. Marshall [Aspers 1999], następnie to zagadnienie badali i dowodzili jego słuszności J. Takeuchi [Takeuchi 1991] i P. Scranton [Scranton 1997]. Powstanie klastra SIDE-CLUSTER również potwierdza tę tezę.

\subsection{Branża klastra SIDE-CLUSTER i jego znaczenie dla rozwoju regionu}

Profil działania klastra SIDE-CLUSTER to ekologiczne, energooszczędne budownictwo drewniane.

Budownictwo drewniane, szczególnie w aspekcie ekonomiczności, ekologii i konieczności zwiększenia mobilności społeczeństwa, jest branżą, która ma duży potencjał innowacyjny, przedsiębiorczy i duże perspektywy rozwoju, nie tylko na rynku polskim, co jest poparte badaniami ekonomicznymi [Economidou 2011], a także doświadczeniem własnym klastra. Zmiana tendencji budowlanych i powrót do tradycyjnych, naturalnych materiałów to sposób na ograniczenie niekorzystnych zmian klimatycznych. W efekcie prowadzonej przez SIDE-CLUSTER ponad 6-letniej działalności edukacyjnej dotyczącej budownictwa drewnianego następuje zwiększenie świadomości społeczeństwa (w tym również ekspertów branżowych) na temat wysokiej wartości budownictwa drewnianego i jego przewagi w odniesieniu do tradycyjnych form budownictwa. Ponadto SIDE-CLUSTER, realizując swoją misję, dąży do połączenia tradycji z nowoczesnością i ekologią - stworzenia ekologicznego, energooszczędnego, tradycyjnego domu śląskiego, o konstrukcji drewnianej, który będzie nawiązywał do tradycyjnego regionalnego stylu budownictwa, a jednocześnie odpowiadał najnowszym trendom i oczekiwaniom klientów. Ma to być produkt sztandarowy, promujący Dolny Śląsk w Polsce i za granicą. Wszystkie działania prowadzone przez klaster (m.in. współpraca z sektorem $\mathrm{B}+\mathrm{R}$, transfer dobrych praktyk krajowych i zagranicznych, wymiana doświadczeń, budowanie i umacnianie więzi w klastrze) prowadzą do tego celu.

Klaster, wskutek umacniania potencjału i wzrostu kompetencji, podejmuje działania w celu pozyskania dostępnych form wsparcia (np. bierze udział w konkursach ogłaszanych przez Polską Agencję Rozwoju Przedsiębiorczości PARP, programie Long Life Learning, próbuje pozyskiwać preferencyjne pożyczki z funduszu JEREMIE na rozwój firm członkowskich). W bardzo dużym zakresie wykorzystuje także pracę społeczną członków klastra (szczególnie koordynatora, animatora, kilku aktywnych przedsiębiorców), bierze udział w programach stażowych jako instytucja nie tylko wysyłająca swoich członków na staż (np. miesięczny staż członka klastra w biurze projektowym przy Uniwersytecie w Alicante w 2013 r., miesięczny staż na Uniwersytecie Bolońskim animatorki klastra w 2012 r., 2-miesięczne staże dla młodych przedsiębiorców będących członkami klastra w 2011 r. na Uniwersytecie w Ferrarze (Włochy) oraz w instytucie naukowym w Budapeszcie), ale również 
przyjmująca stażystów. SIDE-CLUSTER cieszy się dużym zainteresowaniem wśród stażystów polskich i zagranicznych. W ubiegłym roku na miesięcznych praktykach i stażach w SIDE-CLUSTER przebywało 6 osób: 4 studentów i doktorantów z Polski, 1 ekspert z Niemiec, 1 ekspert z Wielkiej Brytanii; w 2012 r. - 5 osób, młodych przedsiębiorców i naukowców: 2 z Węgier, 1 z Wielkiej Brytanii, 2 z Polski, z Dolnego Śląska. W II połowie 2014 r. planowane jest przyjęcie kolejnych stażystów i praktykantów. Dodatkowo klaster współpracuje z wolontariuszami, którzy nieodpłatnie i z własnej inicjatywy pomagają w bieżących działaniach i rozwoju klastra. Pokazuje to, że klastering jest formą współpracy, w której młode, wyedukowane i ambitne pokolenie widzi szansę rozwoju dla siebie i swojego regionu. Dzisiaj bezpłatnie inwestując własny czas, potencjał, wiedzę i umiejętności, wierzą, że wspólna praca i działania prowadzące do realizacji misji SIDE-CLUSTER wkrótce przyniosą zakładane rezultaty. SIDE-CLUSTER stanowi swoisty inkubator przedsiębiorczości i kuźnię młodych talentów. Aktualnie coraz więcej nowych członków klastra stanowią firmy prowadzone przez osoby młode, w tym takie, które wróciły z zagranicy. Pomysły na niektóre firmy powstały właśnie podczas spotkań i wyjazdów organizowanych w ramach klastra. SIDE-CLUSTER stał się inkubatorem nowych pomysłów i nowo utworzonych firm.

\subsection{Dzialania klastra SIDE-CLUSTER związane z rozwojem regionu, realizowane w ramach projektów wspólfinansowanych ze środków publicznych}

Lista projektów zrealizowanych przez klaster SIDE-CLUSTER w latach 2009-2014 jest następująca:

1. Projekt pt. „Klaster SIDE-CLUSTER stymulatorem rozwoju gospodarczego mikro- i małych przedsiębiorstw na Dolnym Śląsku", realizowany od 15.06.2010 r. do 15.12.2010 r., finansowany z budżetu województwa dolnośląskiego w kwocie $100000 \mathrm{zt}$.

2. Projekt pt. „SIDE-CLUSTER liderem ekoprzedsiębiorczości”, realizowany od 1.06.2011 r. do 15.12.2011 r., finansowany z budżetu województwa dolnośląskiego w kwocie 88 624, $00 \mathrm{zł}$.

3. Projekt pt. „SIDE CLUSTER - skuteczne łączenie nauki z przedsiębiorczością", realizowany od 01.06.2012 r. do 15.12.2012 r., finansowany z budżetu województwa dolnośląskiego w kwocie 116 837, 50 zł.

4. Projekt pt. „Rozwój i umocnienie klastra SIDE-CLUSTER poprzez internacjonalizację, łączenie przedsiębiorczości z nauką, ekoinnowacje”, realizowany od 10.06.2013 r. do 16.12.2013 r., finansowany z budżetu województwa dolnośląskiego w kwocie 113 422, 22 zł.

5. Projekt pt. „Zapoznanie przedsiębiorców i specjalistów budownictwa z najlepszymi praktykami niemieckimi w zakresie efektywności energetycznej”, realizo- 
wany od 01.09.2012 r. do 31.05.2014 r., finansowany ze środków Komisji Europejskiej w ramach programu Life Long Learning w kwocie 59 840,00 euro.

6. Projekt pt. „Skandynawskie innowacje w budownictwie - podniesienie kompetencji członków klastra SIDE-CLUSTER", realizowany od 01.08.2013 r. do 31.05.2014 r., finansowany ze środków Komisji Europejskiej w ramach programu Life Long Learning w kwocie 25 031,00 euro.

Dzięki zadaniom wykonywanym w ramach wymienionych projektów nastąpił rozwój endogennych powiązań między aktorami klastra, poprawie uległa integracja środowiska przedsiębiorców branży budowlanej i drzewnej zrzeszonych w SIDE-CLUSTER oraz organizacji badawczo rozwojowych (m.in. Politechniki Wrocławskiej, Uniwersytetu Przyrodniczego), organizacji okołobiznesowych (m.in. Agencji Rozwoju Regionalnego ARLEG sp. z o.o., Agencji Rozwoju Innowacji ARI sp. z o.o.), samorządów (m.in. Urzędu Marszałkowskiego Województwa Dolnośląskiego, Urzędu Miasta Prochowic). Sektory te zbudowały podstawy sieci współpracy dotyczącej innowacyjnych metod prowadzenia działalności gospodarczej, głównie w mikro- i małych przedsiębiorstwach. W wyniku realizacji projektów marka SIDE-CLUSTER została wypromowana na rynku regionalnym, zaznaczyła się na rynkach krajowym i międzynarodowym, jest obecnie rozpoznawalna i utożsamiana z innowacyjnymi technologiami. Wielu przedsiębiorców poznało i doświadczyło pozytywnych aspektów klasteringu, zarówno bazując na działalności SIDE-CLUSTER, jak też poznając dobre praktyki stosowane w Finlandii, Niemczech, we Francji. Poprzez wizyty studyjne i spotkania $\mathrm{z}$ partnerami zagranicznymi klaster SIDE-CLUSTER buduje ponadnarodową płaszczyznę współpracy społeczno-gospodarczej dla dolnośląskich firm.

Duży potencjał i znaczenie umiędzynaradawiania klastrów dostrzega Komisja Europejska, której flagowe inicjatywy „Unia innowacji”, „Polityka przemysłowa w erze globalizacji”, „Europejska strategia wspierania klastrów” [Portal Innowacji] zakładają wsparcie klastrów skali ponadnarodowej, przewidują konsolidację programów wspierających współpracę transgraniczną, w tym m.in. inicjatyw na rzecz tworzenia metaklastrów. Działania SIDE-CLUSTER związane z internacjonalizacją mają na celu przygotowanie klastra do korzystania z możliwości oferowanych przez Komisję Europejską w nowej perspektywie finansowej. „Klastry stanowią katalizator wszelkiej aktywności gospodarczej, przez co wpływają na zmianę postrzegania możliwości i stopnia rozwoju regionu. Dzięki tworzeniu przez klastry sieci powiązań biznesowych w skali ponadnarodowej, w celu współpracy gospodarczej, wymiany doświadczeń i współpracy w obszarach krytycznych dla danych regionów, region staje się bardziej otwarty na wymianę wiedzy i rozwiązań oraz zachęca swoich przedsiębiorców do poszukiwania zagranicznych partnerów" [Łaźniewska, Gorynia 2012]. 


\section{Podsumowanie}

SIDE-CLUSTER powstał w wyniku inicjatywy oddolnej; funkcjonuje na rynku od 2009 r. Jest obecnie w fazie wzrostu. Obserwowany jest dynamiczny rozwój i wzrostu potencjału klastra, który podejmuje działania na rynku lokalnym, regionalnym i krajowym, prowadzi intensywne działania zmierzające do internacjonalizacji klastra i zgrupowanych w nim firm. Aktualnie klaster wprowadza na rynek innowacyjny produkt - mobilny, energooszczędny, ekologiczny budynek mieszkalny i użyteczności publicznej w technologii Teijo-Talot.

\section{Literatura}

A Practical Guide to Cluster Development, 2004, A Report to the Department of Trade and Industry and the English RDAs Ecotec Research \& Consulting, London.

Aspers P., 1999, The economic sociology of Alfred Marshall, „American Journal of Economics and Sociology", vol. 58, no. 4.

Clusters and Clustering Policy: A Guide for Regional and Local Policy Makers, 2010, Committee of the Regions, European Union.

Cluster Benchmarking in Poland - 2010. Survey Report, 2010, Polska Agencja Rozwoju Przedsiębiorczości PARP, Warszawa.

Cooke P., 2002, Knowledge Economics. Clusters. Learning and Cooperative Advantage, Routledge, London.

Economidou M., 2011, Europe's Building under the microscope, Buildings Performance Institute Europe - BPIE.

Gorynia M., 2008, Klastry a międzynarodowa konkurencyjność i internacjonalizacja przedsiębiorstw, Difin, Warszawa.

Identyfikacja istniejacych i potencjalnych klastrów na Dolnym Śląsku, 2009, ECORYS Polska Sp. z o.o. na zlecenie Urzędu Marszałkowskiego Województw Dolnośląskiego, Wrocław.

Ketels Ch., Lindqvist G., Solvell O., 2007, Cluster and Cluster Organization, Center for Strategy and Competitiveness, Stockholm School of Economics.

Kierunki i polityka rozwoju klastrów, 2009, opracowanie Ministerstwa Gospodarki, Departament Rozwoju Gospodarki, październik.

Łaźniewska E., Gorynia M., 2012, Konkurencyjność regionalna. Koncepcje - strategie - przykłady, PWN, Warszawa.

Peters E., Hood N., 2000, Implementing the cluster approach, „International Studies of Management and Organization", vol. 30, no. 2.

Portal Innowacji, Polska Agencja Rozwoju Przedsiębiorczości, 2014, Warszawa, http://www.pi.gov.pl/ PARP/chapter_86197.asp?soid=13B041DE9F5045EC9EBA708D4D698A76.

Porter M.E., 1990, Competitive Advantage of Nations, Macmillan, London.

Porter M.E., 2000, Location, Competition and economic development: Local clusters in a global economy, „Economic Development Quarterly”, vol. 14, no. 1.

Rabellotti R., 1995, Is there an ,industrial district model” footwear districts in Italy and Mexico compared, „World Development”, vol. 23, no. 1.

Raport o stanie sektora MSP w Polsce w latach 2011-2012, 2013, Polska Agencja Rozwoju Przedsiębiorczości PARP, Warszawa. 
Rymarczyk J., 2012, Biznes międzynarodowy, Polskie Wydawnictwo Ekonomiczne, Warszawa.

Scranton P., 1997, Endless Novelty: Specialty Production and American Industrialisation 1865-1925,

Princeton University Press, Princeton.

Small Business (SBA) Fact Sheet, 2012, European Commission, Brussels.

Steinle C., Schiele H., 2002, When do industries cluster? A proposal on how to assess an industry's propensity to concentrate at a single region or nation, „Research Policy”, vol. 31, no. 6.

Takeuchi J., 1991, The Role of Labour-Intensive Sectors in Japanese Indutrialization, United Nations, University Press, Tokyo.

Wierżyński W., 2010, Klastry - wspótzależność przez współdziałanie, „,Biznes Klaster”, nr 2/2010, Klaster Instytucji Otoczenia Biznesu.

www.clusterscord.eu. 